\title{
Self-interest, deregulation and trust
}

\section{Salvör Nordal}

In this paper I will discuss Milton Friedman's thesis that the social responsibility of business is to maximize the shareholders' profit. I examine the underlying assumption of self-interest and argue, contrary to the neoliberal thesis of deregulation, that the profit motive must be constrained by strong state regulations. Furthermore it facilitates keeping the division between business and government intact. The financial crisis shows that the emphasis on a profit motive without the external constraints of tight regulations has serious implications for the trustworthiness of business. In the latter part of the paper I will discuss trust in relation to self-interest. The overemphasis on self-interest is particularly unfortunate in connection with business, and not least the financial sector, as this institution is grounded in trust, without which it cannot survive. Seen from this angle, it can be claimed that a business model, celebrating primarily self-interest, profit-motive and deregulation, is not going to be sustainable in the long run.

Key words: social responsibility, self-interest, trust, deregulation, Milton Friedman

The forces unleashed with the fall of the Lehmann Brothers in the US had immediate effect throughout the world and shortly thereafter it became evident that the effect in Iceland would be disasterous. ${ }^{1}$ Within four weeks, all three big banks in the country had collapsed; an emergency law had been issued through parliament, and Iceland would soon become the first Western society in decades to ask for support from the International Monetary Fund. ${ }^{2}$ The banking crisis in Iceland received worldwide attention and undoubtedly gave some leaders of Western countries a shiver down their spine, not only because of the size of the banks and, due to huge debts, the effect their collapse might have on foreign creditors, but also because what was materializing in Iceland might be an indication of what could soon be 
happening in other countries. The dramatic changes that took place in Iceland, from being one of the richest countries in the world to seeking financial assistance, affected its citizens in profound way. The trust towards business and the government was questioned; a revision of values was called for, and people were eager to understand why the international financial crisis had hit Iceland so hard. There is neither an easy nor a simple explanation of what happened in Iceland; the blame is due to global and local practices, individual and institutional recklessness, and has its roots in an ideology gone astray. Analysis of the crisis in Iceland has already started and will surely continue for the coming years. ${ }^{3}$

Interestingly, the countries hardest hit by the international financial crisis, such as Iceland, Ireland, Britain, and the US, have represented the neoliberal view of laissez-faire economy. For the past 15 years, the Icelandic economy has been through extensive changes. After becoming part of the European market in 1993, the road towards an open and free economy was paved with privatization, deregulation and reduced taxes. The Icelandic banks were fully privatized in 2003 and from then on Icelandic bankers and businessmen were ready to storm into international markets for expansion and profit. Friedman's thesis that the social responsibility of business is to maximize shareholders' profit was hailed, and in retrospect we can sense the overwhelming power of the majority owners in Icelandic banks and corporations.

In Friedman's article 'The social responsibility of business is to increase its profits' (Friedman 1991), we find a clear and a lucid defence of the thesis spelled out in the title, namely that the responsibility of business is to maximize the profit of owners, i.e. stockholders. Certainly, Friedman is not the first to put this into words but his article has become highly influential, not only in theoretical debates on the matter but it is also embraced in the real business of free-market economies. According to Friedman, only individuals have responsibilities, not corporations, and in this respect he has three main arguments. First, firms and corporations operate in free societies on their owners' responsibility. Executives are hired by owners to run their companies and maximize the owners' profits. Second, Friedman argues that when an executive spends money on social issues he or she is using other people's money equivalent to imposing taxes on them; he claims this to be socialism. Third, Friedman maintains that using the term 'social responsibility' for such exercises is hypocritical since the reason for money being spent is often for the purpose of marketing or to maintain a corporation's good name. All three arguments deserve careful attention. In the following, I will primarily discuss the first two and argue that, contrary to the neoliberal thesis of deregulation, the profit motive must be constrained by strong state regulations, which facilitate keeping the division between business and government intact. Furthermore, the financial crisis shows that the empha- 
sis on a profit motive without the external constraints of tight regulations has serious implications for the trustworthiness of business. The overemphasis on self-interest is particularly unfortunate in connection with business, and not least the financial sector, as this institution is grounded in trust, without which it cannot survive. Seen from this angle, it can be claimed that a business model, celebrating primarily self-interest, profit-motive and deregulation, is not going to be sustainable in the long run.

\section{Self-interest and the profit motive}

The union between self-interest or the profit motive and business has been strong ever since Adam Smith famously remarked: 'It is not from the benevolence of the butcher, the brewer, or the baker that we expect our dinner, but from their regard to their own interest. We address ourselves, not to their humanity but to their self-love, and never talk to them of our own necessities but of their advantages' (Smith 1937: 14). This suggests that when a baker bakes the bread he is primarily providing himself with a job and his own 'bread'. We are not in business to serve public goods let alone to perform altruistic deeds; we need to provide for ourselves and our families. In business, both parties need to benefit, the one who sells the bread and the one who buys it. In this sense it is our gain that there are bakers, butchers and brewers attending to their own interests, as ultimately that serves our interests best.

Acting in our self-interest is not necessarily blameworthy and some have even argued that humans always act according to what they believe to be their own interest (Hooker 1998). Even if we do not agree to such a strong claim, in our daily life our actions are often motivated by self-interest. Deciding to study philosophy or pursuing a career in that field, for example, might be primarily motivated by self-interest but it does not become selfish or blameworthy unless by doing so we fail to take the interests of others into account. If my decision to study philosophy restricts me in caring for my children, I have acted selfishly. Similarly, most business decisions are driven by the profit motive and as such are based on self-interest. There is nothing wrong with this unless the profit is at the cost of others whose interests should have been taken into consideration (Hooker 1998). Certainly, it is not always clear when our actions are selfish in this respect or where we should draw the line between selfishness and acting reasonably on self-interest motives. This difficulty becomes evident in business when corporations' decisions affect many people and may cause conflict between the selfinterest of profit making and other obligations. Hence considerations of such conflicts and where the line is to be drawn are important. Otherwise, as Hooker argues, if business people usually resolve such conflicts in favour 
of themselves, and if this usually involves too little concern for the good of others, then selfishness pervades the business world' (Hooker 1998: 35).

The task is therefore to define social responsibility and to solve conflicts of interest in various cases even if we agree that people are in business to serve their own personal interest and to make a profit. For Friedman, the issue is very clear: the executive is responsible towards the owners, whose interest is to have their profit maximized. This, however, is not as simple as it sounds. Maximizing profit is not a simple equation and we may have the possibility to choose from diverse routes to meet the principle, each having different consequences for society. It might be just as important to consider social obligations when deciding between such routes. In the present financial crisis we have also been reminded of the fact that the outcome for the society can be very different if the goal is only to maximize profit for shortterm reasons rather than for long-term reasons. Moreover, Friedman assumes that cases of social responsibility (the ones quoted above) are against the interests of their owners and that the latter will primarily choose to maximize their own interests. It is, however, safe to say that stockholders are a diverse breed and may have very different views on how to run a company. Friedman argues that executives can certainly use their own private money as they please but they must not allocate other people's money at will.

Instead of this narrow view of social responsibility, the stakeholder theory argues for a complex interplay of corporation and society where the focus is on mapping different stakeholders for business such as owners, employers, costumers, suppliers, creditors, competitors, professionals, local community, the state, international community, and the environment (Lucas 1998). This interplay has become evident to most Icelanders now, after having become responsible for the financial system and at least for part of its debts. Furthermore, employers have lost their jobs, customers have lost their savings, and suppliers have been left with unpaid bills and creditors with reduced assets. On top of all this, not only the trust towards individual corporations has been lost but also international trust towards Iceland as a nation is deeply affected. In fact, it can be said that the collapse of the Icelandic financial system shows us vividly how the responsibility of business is interconnected with society as a whole. Moreover, it is not unreasonable to ask whether bank directors have more responsibility towards the owners or to the people who have entrusted them with their savings.

The above discussion shows how simplified it is to look only at the responsibility towards owners. Given that the shareholders lost all of their assets in the Icelandic banks in the crash, Friedman might argue that the directors had failed their principal obligation towards them. If they had taken their responsibility towards their owners seriously enough, the banks would have survived and would have been able to uphold their obligations to others. It seems, however, that too much emphasis on maximizing profit 
may also have confused the executives, some also being owners, and possibly generated reckless behaviour and too much risk taking. Furthermore, this points to the fact that the financial system is no ordinary business. No modern society can function without banks - a situation Iceland faced when its entire banking system was on the verge of collapse. At that time, Iceland's Government needed to take immediate action to secure the operation of the basic system and take on responsibilities of the private enterprise. It was then that it became evidently clear that the banking system is there to serve public interests and has obligations to society as a whole.

\section{Deregulation and the minimal state}

Friedman links the social responsibility of business with socialism. He argues that it is not the role of the executives but of government and public servants to take care of public matters and work for public interest: 'he [the executive] is imposing taxes [...] and deciding how the tax proceeds shall be spent' (Friedman 1991: 42). As such, the executive is taking on the role of government, a role that he is not skilled for, and he becomes in effect a public employee, a civil servant, even though he remains in name an employee of a private enterprise' (Friedman 1991: 43). This requires different skills and interests. Executives are not trained to fight inflation, define environmental standards, or organize other social projects of similar kinds; this is the job of government and public institutions. Executives, on the other hand, are experts in running business. Friedman maintains: 'There is one and only one social responsibility of business - to use its resources and engage in activities designed to increase its profits so long as it stays within the rules of the game, which is to say, engages in open and free competition without deception and fraud' (Friedman 1991: 45). He highlights here the importance of legal framework and that the executives play by the rules of the game.

Friedman's argument sounds quite sensible and is in many ways persuasive. Is it not obvious that executives should focus on their job and run their business as well as they can? Is this not in accordance with the traditional division of labour on which our society is grounded? In a modern society of high expertise everyone has his or her role and it serves society best if they attend to their obligations as best they can without interfering too much in other people's business. According to Friedman it is not simply that it is the role of the public sector to attend to public interest but also that at the end of the day it serves public interest best if everyone attends to his or her own interest: 'The difficulty of exercising «social responsibility» illustrates, of course the great virtue of private competitive enterprise - it forces people to be responsible for their own actions and makes it difficult for them to 
«exploit» other people for either selfish or unselfish purposes. They can do good - but only at their own expense' (Friedman 1991: 43).

Here, I will focus on how Friedman's view on strong division between the role of business and public affairs or the governmental sector accords with the neoliberal thesis of keeping the role of government to the minimum. On the one hand, there is Friedman's view that responsibility of business is very limited, only to maximize profit. On the other hand, the state should be minimized with fewer regulations. As such, the state will hardly be capable of taking responsibility for tasks which the business sector does not cover. Who, then, bears these responsibilities? Interestingly, the examples Friedman gives as social responsibilities are fighting inflation, reducing the social cost of unemployment by hiring those who have been unemployed for a long period; and setting stricter environmental standards than legally required. None of these cases are of a kind that can be tackled by individuals on their own. Neither executives nor shareholders can work privately to improve environmental standards or fight inflation. On the contrary, these are precisely tasks for business firms or public institutions. To set adequate standards for the environment requires, for instance, strong professional institutions where policies are defined with the possibility of monitoring the standards. Obviously, with weaker government, or a minimum state, there is less capacity to handle this role and address the problems. This point is especially interesting in the light of the financial crisis in Iceland since, due to its small size, the Icelandic public sector is less capable of running professional institutions with enough power to set standards for the banking sector (Jännäri 2009). One can even claim that exactly because of the smallness of the Icelandic state, it failed to set limits for the financial sector. This said, the perspectives on simplified business responsibility and minimal state are actually pulling in opposite directions. If responsibility in business life is only to maximize the profite of shareholders and to stay within the rules of the game, someone must be available to handle both the task of setting the rules and taking on the tasks which business leaves out. This does not require a small state; on the contrary, it requires a strong state with professional institutions. Friedman's argument therefore rests on the assumption that there is a public sector setting adequate standards. Underlying this is a very clear division of responsibility; the responsibility of business and the responsibility of the state, where the latter has an important role to play. If responsibilities are moved from one they must go to the other, they do not simply evaporate.

So far I have argued not only that the principle of self-interest and profit motive must be limited by rules and regulations but this requires a strong state rather than a weak one. In many ways my argument is in line with that of Adam Smith. The quotation from Adam Smith above has been interpreted in such a way that his view is that each person should think of himself or herself. It is, however, important to note that Smith was also very much 
interested in the limits of the market, arguing for a strong state. He was concerned with how society should address poverty and other issues which the market could not address (Sen 2009). Furthermore, it is important that market values such as competition and self-interest do not corrupt other spheres of human life, spheres that should rather be characterized by virtues such as humanity, justice and generosity.

\section{Deregulation and trust}

Self-interest and individualism are often seen as two sides of the same coin (Hooker 1998). One of the characteristics of individualism is the emphasis on the individual apart from others. Individual autonomy is, for instance, the ability to make choices based on individual preferences and attitude towards the world. The individual becomes the centre of the universe and the focus is on his or her own decisions with a range of choices enabling him or her to act as a free and autonomous agent. As such, individual autonomy has become a leading topic in modern ethics and in discussions on, for instance, biomedical ethics.

Recently, the prevailing notion of individual autonomy has been criticized for undermining trust, among other things. As O'Neill argues, trust and individual autonomy are pulling in different directions. Trust means relying on others, whereas individual autonomy is 'expressed when we are least constrained by others and their expectations. Trust flourishes between those who are linked to one another; individual autonomy flourishes where everyone has «space» to do their own things. Trust belongs with relationships and (mutual) obligations; individual autonomy with rights and adversarial claims' (O’Neill 2002: 25).

Instead of individual autonomy, Onora O'Neill argues for principled autonomy, rooted in Kantian ethics. This understanding of autonomy is committed to a set of principles which reject deception and coercion. Rather than placing moral commitment primarily on rights, O'Neill highlights obligations as an inseparable part of rights. She does not make the strong claim that obligations are more fundamental than rights, but states that obligations are the 'anchor' for rights. The advantage of highlighting obligations depends on the structural connections between rights and obligations. If someone has a right then someone else must have a duty to respect that right. Moreover, obligations are always talked about in terms of the language of action, whereas rights are often abstracted from actions. Consequently, there have been claims for rights, such as the right to health, without giving any thought to what obligations follow from it. Obligations are therefore less vague and more precise than rights and they identify specific actions that should be taken or avoided, and as such they determine 
what conduct is called for. Finally, according to O'Neill the language of obligation highlights the relationship between the holders of rights and obligation bearers, which means that rights are not individualistic in the strongest terms but correlate to other people and their obligations.

Thus we can see the central role obligations have for principled autonomy and hence for anchoring rights. The merit of principled autonomy is that it focuses on relationships between individuals and on trust and trustworthiness. It is hard to imagine a good society without a considerable amount of trust. Trust is needed in our social life, where it has been described as the glue that holds it together (Govier 1997). Trusting a person means that we believe he or she is going to live up to certain expectations and we trust not only our immediate friends in such a way, but also professionals, even complete strangers, as well as practices and institutions. Trusting someone does not only mean that we rely on another's goodwill but also that the person is sufficiently competent to live up to our expectations (Sutrop 2007: 191-192). As such, the person has to be worthy of our trust. We often take trust for granted and do not see its value until we experience the opposite condition, distrust: 'Distrust exists when there is a lack of confidence in the other, a concern that he or she may act so as to harm us, that he or she does not care about our welfare, intends to act harmfully, will not abide by basic moral norms, or is hostile towards us. When we distrust, we are fearful and suspicious about what the other might do' (Govier 1997: 34).

There is little consensus on how to define the concept of trust and it has been described in various ways as a feeling, an emotion, a disposition, an activity, a knowledge, and a reliance (Sutrop 2007: 191). Solomon and Flores (2001) distinguish between four types of trust. Simple trust is taken for granted without any suspicion and reflection. Basic trust usually begins without thought or reflection and provides a general orientation or attitude to the world. Blind trust is essentially self-deceptive and denial in the face of obvious evidence. One sees but refuses to see. Authentic trust is open to evidence. It is a product of experience and commitment and carries with it the possibility of distrust (Solomon \& Flores 2001: 65-66). Solomon and Flores argue that authentic trust is dynamic and open to new possibilities, as such trust is not given once and for all but is a choice that is made conscious of the possibilities of distrust.

In one way or another, business life rests on trust. When we buy products we trust we will receive what is promised. We borrow and lend goods and money and we trust that the bills will be paid in due course. Then, one day in September 2008, trust in the global financial system disappeared: the system was shaken and in some places it collapsed. Overnight, not only had the trust between the banks disappeared and no one was willing to lend anything to anyone anymore, but also the general public desperately started withdrawing cash from their banks and bank runs became a reality. Distrust 
became the rule, not the exception. Even if we do not think about trust when everything is going well, at least we know now from a bitter experience that trust is built up over long period of time but it can disappear overnight as a result of reckless behaviour.

The present financial crisis has vividly manifested not only how extraordinary fragile trust can be but more significantly the importance of those regarded as being worthy of our trust. As the financial crisis unfolds it has become more and more evident that the financial system has failed to live up to its claim to trustworthiness. Many of the new products of the financial market such as Credit Default Swaps (CDS) and Collateralized Debt Obligations (CDO) were designed in such a way as to minimize the responsibility of the risk takers. The products were complex and opaque which made it difficult both to analyse and to understand, and as such hard to regulate. There is even evidence that the designers made an effort to confuse regulators and to get around existing regulation (Tett 2009). ${ }^{4}$ This was done with the intention of having the link between risk taking and responsibility removed or severely weakened. Needless to say, these products were hugely successful and profitable for many of the big investment banks.

The construction of the new products show that the financial sector was not living up to its basic obligations to its customers or society at large. Furthermore, it seems that the banks were trusted blindly. Despite some evidence put forward of weakness in the financial system in Iceland, society in general turned a blind eye: while the party was still going on there was simply no grounds for taking such a criticism seriously. Unlike politicians, regulators and the media, the general public did not have the expertise to examine evidence of weakness. Unfortunately, it seems that too many were willing to play along. Unfortunately, too, the democratic public sphere has been deteriorating in many countries and politicians have been more willing to play along with the business sector rather than controlling it.

Given that trust can be blind, it is not always virtuous to trust. Hence the literature on trust has focused on trustworthiness. Who is worthy of our trust? How can we build trustworthy institutions? According to Hardin, the communicating commitment important for establishing trustworthiness is secured by three devices of social constraints (Hardin 1996). The first device is small-scale constraints on personal relationships with people we associate with on a daily basis. The second device requires large-scale control of law and other institutional constraints with legal enforcements. Third, operating between the first two devices, there are mixed devices of religious controls and also social norms and practices (Hardin 1996: 31). To establish trustworthiness in business it seems that all three devices are needed. There must be constraints in personal relations within each corporation, the legal constraints must be in place, and the overall practices of business must constrain certain actions. 
In all cases, the aforementioned adequate constraints failed to secure the trustworthiness of the 'financial market'. Many have focused on the lack of external regulations as one of the main causes of the crash, but in the absence of external regulations the business culture failed also in setting standards from within. Therefore it has become apparent, contrary to Friedman's thesis, that private competitive enterprise does not necessarily force people to be responsible for their actions. Moreover, selfishness and greed replaced healthy self-interest. Greed in business is self-interest and profit motive gone badly off track, and now we face the task of not only building the trust towards specific corporations but also business life in general. Stronger regulations and limits on the banking system are therefore important lessons of the financial crisis, or as was stated at a recent symposium on the matter: 'As we look to the future we also have to look at the mistakes policy makers made in the last ten years. It's not news that people are greedy. But we made conscious decisions not to put limits on that natural human impulse' (Bradley 2009).

We have seen how unconstrained self-interest undermines trustworthiness in business. Trust flourishes when we take others into consideration and think about our obligations towards them. As such, our obligations in personal life, let alone in business, cannot be narrowed down to just one or two. Instead, we have to acknowledge that we live in a complex web of interrelations where we have important and diverse obligations. This requires defining limits to self-interested behaviour, which in turn requires regulations and strong governmental sectors. We need to control greed in business as in other sectors of human life, because we have seen only too well that the social cost of selfish gambling is simply much too high. ${ }^{5}$

\section{Notes}

1 Some have argued that the Icelandic banks would have collapsed with or without Lehman Brothers; regardless, it is a fact that the fall of Lehman Brothers marked the beginning of the end.

2 The UK was forced to call on the IMF for support in 1976.

3 Under Act No. 142/2008 a special Investigation Commission (SIC) was established by the Icelandic Parliament. The Commission's mandate is to seek the truth relating to the events leading to, and the causes of, the downfall of the Icelandic banks, and related events.

4 Gillian Tett (2009) explains vividly how these products came into being and how the producers tried to get around regulations in her book Fool's gold. How unrestrained greed corrupted a dream, shattered global markets and unleashed a catastrophe.

5 Thanks are due to Janet D. Sisson, Vilhjálmur Árnason and two autonomous reviewers for commenting on earlier version of this paper. 


\section{Literature}

Bradley, B. (2009) The crisis and how to deal with it. Presented at The New York Review of Books Symposium. The New York Review of Books, Vol. LVI, No. 10, June 11-July 1, 2009.

Friedman, M. (1991) The social responsibility of business is to increase its profits. In Business ethics in Canada ( $2^{\text {nd }}$ ed.), eds. D.C. Poff \& W.J. Waluchow, pp. 4145. Canada: Prentice Hall.

Govier, T. (1997) Social trust and human communities. Quebeck: McGill-Queen's University Press.

Hardin, R. (1996) Trustworthiness. Ethics, 107 (October 1996), pp. 26-42.

Hooker, B. (1998) Self-interest, ethics, and the profit motive. In Business ethics. Perspectives on the practice of theory, eds. C. Cowton \& R. Crisp, pp. 27-41. Oxford: Oxford University Press.

Jännäri, K. (2009) Report on banking regulation and supervision in Iceland: Past, present and future. Available at http://www.forsaetisraduneyti.is/frettir/nr/3582

Lucas, J.R. (1998) The responsibility of the businessman. In Business ethics. Perspectives on the practice of theory, eds. C. Cowton \& R. Crisp, pp. 59-77. Oxford: Oxford University Press.

O’Neill, O. (2002) Autonomy and trust in bioethics. Cambridge: Cambridge University Press.

Sen, A. (2009) Capitalism beyond the crisis. New York Review of Books, 65 (5), March 262009.

Smith, A. (1937) An inquiry into the nature and causes of the wealth of nations. The Modern Library. New York: The Random House.

Solomon, R.C., \& Flores, F. (2001) Building trust in business, Politics, relationship, and life. Oxford: Oxford University Press.

Sutrop, M. (2007) Trust. In The ethics and governance of human genetic databases, V. Árnason, G. Árnason, R. Chadwick, \& M. Häyry (eds.), pp. 190-198. Cambridge: Cambridge University Press.

Tett, G. (2009) Fool's gold. How unrestrained greed corrupted a dream, shattered global markets and unleashed a catastrophe. London: Little, Brown. 